AWEJ for Translation \& Literary Studies, Volume 5, Number4. October 2021

Pp. 92-108

DOI: http://dx.doi.org/10.24093/awejtls/vol5no4.8

\title{
Evaluation of Wadjda: A Comparative Discourse Analysis of Western and Saudi Movie Reviews
}

\author{
Maram Saleh Almohaimeed \\ English Language Skills Department, Common First Year \\ King Saud University \\ Riyadh, Saudi Arabia \\ E-mail: msalmohaimeed@ksu.edu.sa
}

Abstract Received: 8/25/2021

Accepted: 9/18/2021

Published:10/24/2021

Since people are showing more interest recently in movies and as movie reviews of the same movie could vary in the degree of their objectivity, this paper seeks to answer why movie reviews may differ in their evaluation of the same work. To this end, a critical discourse analysis using Fairclough's three-dimensional framework and Martin and White's attitude framework is carried out to analyze two reviews of the Saudi movie Wadjda, one written in English by a western critic, and the other is Arabic written by a Saudi critic. The textual analysis of attitudinal expressions shows that the English text maintains an even distribution between the negative and positive expressions, and most of the negative expressions do not assess the aspects of the movie but rather the Saudi society. In the Arabic text, however, the negative expressions outnumber the positive ones, and they are mostly related to the movie and the director. Using Fairclough's framework, the author explains the findings of the textual analysis of the English review and the critic's avoidance of negative evaluation as a result of Eurocentrism and the way the western media represent Arabs and Muslims. However, the negative appraisal of several movie aspects found in the Arabic review could be seen as a result of the critic being part of the society and, thus, not distracted by the social issues.

Keywords: attitude framework, critical discourse analysis, Fairclough, movie review, threedimensional framework, Wadjda

Cite as: Almohaimeed, M. S. (2021). Evaluation of Wadjda: A Comparative Discourse Analysis of Western and Saudi Movie Reviews . Arab World English Journal for Translation \& Literary Studies 5 (4) 92-108. DOI: http://dx.doi.org/10.24093/awejtls/vol5no4.8 


\section{Introduction}

Film critics have a powerful influence on people's decision to watch a particular movie or not (Hsu, 2006). This influence has become even more robust with the available media outlets where film critics can publish their reviews. Film critics watch new movies and write critiques on different aspects of these movies: the plot, the direction, the chemistry between characters, etc. They provide an honest evaluation and maintain an objective assessment of the quality of the work. However, film critics are influenced in their writings by their ideologies, cultural differences, and common stereotypes about other societies. This influence, sometimes, can be sensed in their reviews when making judgments about other cultures, cultures that are different from theirs. This case has caught the researcher's eye in movie reviews about the Saudi movie Wadjda. Many movie critics wrote about it on varioius platforms, and some of these critiques were not bias-free to the Saudi society. To better understand these movie reviews, Critical Discourse Analysis (CDA) offers an approach not only to critique discourse but also to explain its relation and contribution to the existing reality to achieve change (Fairclough, 2015).

It has been noticed that movie reviews of the same movie could vary in the degree of their objectivity. One reason for such variation seems to be the relationship between the movie critic and the society's culture being represented in that movie. Another reason could be the influence of how the mass media portray other cultures. Through critical discourse analysis, this paper can shed light on the discourse of movie reviews from a social angle that has not been investigated. This paper seeks to answer the following questions:

1. To what extent do the two movie reviews differ in their appraisal of Wadjda?

2. What are the reasons that can explain the different evaluations the two reviews present? The aim of this analysis is to investigate how the Saudi movie Wadjda is evaluated in two movie reviews to arrive at some explanation for the different evaluations the same movie receives from different critics. It seems that there are reasons that may turn the focus of movie critics from criticizing the cinematic and technical aspects of movies to criticizing the societal background of these movies, and this paper tries to uncover these reasons.

\section{Literature Review 'Wadjda' Movie Movie Critics}

Wadjda is the first feature movie entirely shot in Saudi Arabia. It is written and directed by Haifa Almansour, a Saudi woman. The movie is partially financed by Rotana, a company owned by the Saudi Prince Alwaleed bin Talal, and produced by the German Gerhard Meixner and Roman Paul. The movie's events revolve around a young and determined Saudi girl who tries to challenge some of society's traditions. As portrayed in the movie, being not allowed to buy the bicycle that has attracted her attention is one of these constraining traditions she has to confront. The rest of the events, then, show how hard she tries to get that bicycle by joining the Qur'anic recitation competition to win the cash prize. The movie, in general, sheds light on Saudi women's issues in facing some social constraints. 
It casts no doubt that movie critics have a significant impact on movie audiences. A great body of research has investigated the influence of movie reviews, mostly for marketing purposes. For example, Liman (1983) examined several variables to see their influence on the cumulative performance of films and concludes that critics' rating was one of the most important predictors of the performance of the market. Similarly, an article published in Wall Street Journal proclaimed that positive movie reviews attract the audience to watch a certain movie. This, in fact, reflects what Weimann (1991) thought of critics in general as "opinion leaders." Opinion leaders, as described by Assael (1984), are considered to some people sources of information and advice since they have the knowledge and expertise on a certain subject. According to Hall (2001), movie critics' influence is also perceived in their contribution to how audiences manage and interpret a variety of movies' embodied ideologies. Hence, critics help to maintain existing systems of belief and to promote social change. Realizing this vital role of critics, a great body of literature has investigated movies and their reviews. However, some of these studies focused on the movie critics and reviews from a financial perspective as a tool that affects film revenues. Others examined how a specific issue such as gender or race is tackled by movie critics. Therefore, this paper will try to fill the gap by situating movie critics and reviews in an interactional and social context using critical discourse analysis.

\section{Media and Attitudes}

The way some cultures are represented in the media could have an impact in drawing stereotypical images about these cultures and, as a result, affects the judgments made about these cultures (Kassimeris \& Jackson, 2011). Western media maintain a persistent distorted image of Muslims and Arabs and always deal with them as identical entities (Abdel Moneim, 2016; Hall, 2001; Macdonald, 2006; Ridouani, 2011). Shaheen (2003) argued that Hollywood has been for a long time unjust to Muslims and Arabs, portraying them as religious and uncivilized. He further described how these negative portrayals have power in shaping social attitudes and beliefs and making lenses through which people view the world.

\section{Ideologies and Attitudes}

Attitudes and judgments about others can also be shaped by ideologies. Ideologies, according to van Dijk (1995), are defined as "basic systems of fundamental social cognitions and organizing the attitudes and other social representations shared by members of groups" (p.243). Eurocentrism is an ideology that may affect the Westerns' attitudes toward those who belong to different cultures. According to Hobson (2006), Eurocentrism is based on the premise that the European experience is privileged, and it is characterized by superiority and universality. Eurocentrism holds that the Westerns are the superior and their values are universal and can be adopted by others; following the path of the Westerns is the only way to achieve development and modernity.

\section{Ideology and Discourse}

Ideology and discourse are interrelated, with discourse being the most noticeable manifestation of ideology. Therefore, only through ideology, can one question a certain frame of interpretation (Verschueren, 2015). The research of ideology in discourse originated in the works 
of critical linguistics and later, with the advent of Systemic Functional Linguistics (SFL), it continues under the research of critical discourse analysis (Teo, 2000; Riasati \& Rahimi, 2011).

In CDA, the goal is to adopt a critical approach to language use which affects and is affected by social practices and processes (Verschueren,2015). Many scholars have contributed to CDA with some theoretical frameworks. Fairclough, for example, has developed a threedimensional critical framework, the first and the most significant to the field (Riasati \& Rahimi, 2011). Fairclough's framework consists of three stages: the description, the interpretation, and the explanation. The description stage is concerned with the textual properties of the text. As guidelines for analysts, Fairclough has proposed ten questions related to the experiential, relational and expressive values of vocabulary and grammatical structures employed in the text. In the interpretation stage, the focus is on the relationship between text as a product and a resource for the interpretation process and interaction. The explanation stage examines "the relationship between interaction and social context" (Fairclough, 2015, p. 59). Analysts in this stage look at the social determinants and effects that shape the production and interpretation processes (Fairclough, 2015). Martin and White (2005) have also contributed to CDA with their appraisal theory, the basis of which rests on Halliday's work in SFL. The Appraisal Theory is concerned with the interpersonal metafunction in language. It investigates the stances of speakers or writers towards the materials they present and towards those with whom they interact. The Appraisal Theory proposes three frameworks: attitude, engagement, and graduation. For this research, the focus is going to be only on the framework of attitude. Attitude encompasses three semantic regions: affect, judgment, and appreciation. Affect is concerned with positive and negative emotional evaluations of states of affairs, things, and processes. Judgment here refers to the ethical evaluation of human behaviors, while appreciation refers to "evaluations of semiotic and natural phenomena, according to the ways in which they are valued or not in a given field" (Martin \& White, 2005, p.43). To get a clear picture of the appraisal language in a certain text, both inscribed and invoked attitudes should be considered. Inscribed attitude is expressed overtly while invoked attitude is pointed out implicitly (Thompson, 2014). The attitude framework can help analyze the attitudes of movie critics as they are generally constrained by their belief systems upon which they rely in their evaluation of movies' quality (Hsu, 2006).

\section{Methods}

To achieve the aim of this research, two movie reviews about Wadjda were selected and obtained from the websites of their sources (see appendix A). The first one is an English review written by Violet Lucca and published in Film Comment magazine, a magazine published since 1962 by the Film Society of Lincoln Center and well-known for movie reviews. The second article is an Arabic review written by Tami Alsmairi and published under the 'culture' section in Alriyadh newspaper, a famous Saudi paper.

To find about the critics' appraisal language, Martin and White's attitude framework was used in the analysis of the textual level. For each text, all attitudinal expressions were marked and grouped in a table based on their type: affect, judgment, or appreciation. The "appraiser" and the "appraised", the source and the target of the attitude respectively, were identified for each attitudinal expression. Its orientation, whether positive or negative, was specified in the same table 
as well. For the Arabic review, the appraisal expressions were first identified and then translated into English. For more critical analysis, Fairclough's framework was employed to find the relationships between the text and interaction and between interaction and social context. To clarify, the texts were analyzed in terms of the interpretation and explanation stages of Fairclough's framework. In the interpretation stage, the texts were analyzed based on their discourse type and their relations to the situational and intertextual contexts. This stage was also guided by looking at how language was used to instantiate some of the seven-building tasks proposed by Gee (2014). These building tasks are Significance, Practices, Identities, Relationships, Politics, Connections, and Sign Systems and Knowledge. In the explanation stage, the analysis of the texts looked at the social determinants that influenced the production process of these texts and the social effects these texts might have in sustaining or changing the social struggles.

\section{Textual Analysis}

Using the attitude framework, the analysis of the first review written by Violet Lucca shows that the critic uses many appraisal expressions, most of which are expressions of judgment and appreciation (see appendix B for detailed analysis). Regardless of who or what is being appraised, the language of appraisal used by the critic generally maintains a balance in its orientation, be it positive or negative (see table one). By looking at who and what is being appraised, it can be noticed that the review is not primarily addressing issues unique to the film-making; i.e., the director, the cast, the plot, or the events. What is being appraised in this review goes beyond the movie. The critic attempts to relate the events of the movie to what is happening in the movie's home country, Saudi Arabia. This is evident in almost half of the appraisal expressions used to appraise the Saudi society, Prince Alwaleed bin Talal, and Rotana Group.

\section{Table 1. Number of appraisal expressions in the English review}

\begin{tabular}{|c|c|c|c|}
\hline \multirow{5}{*}{$\begin{array}{c}\text { The English } \\
\text { Review } \\
\text { (wordcount: 798) }\end{array}$} & Total positive expressions & 32 & \multirow[b]{2}{*}{ Total 66} \\
\hline & Total negative expressions & 34 & \\
\hline & Affect & 6 & \multirow[b]{3}{*}{ Total 66} \\
\hline & Judgement & 36 & \\
\hline & Appreciation & 24 & \\
\hline
\end{tabular}

This movie review tells the story of the movie with some interesting details accompanied by the voice of the author. In fact, although the author refrains, for the most part, from giving negative criticism to the movie, she does express her perspectives about Saudi society. This is clear in expressions like: "outspoken radicalism and political passivity", "the sad confirmation of the social order", "the contradictions of Saudi society", and "female actors are generally shunned".

In the second review written by the Saudi author, Tami Alsumairi, it is clear that the author mainly focuses on the movie and all issues related to it, situating the movie as an example work that resembles many previous works in the Saudi cinematic context (see appendix C for detailed analysis).

Unlike the first review, this review seems to be dominated by negativity (see table two). The negative expressions of appraisal are almost double the number of the positive expressions. The author negatively appraises the situation of the Saudi cinema, movie production in Saudi 
Arabia, and Saudi directors and novelists. However, the majority of the negative expressions pertain to the movie, the director, and the characters. Among many aspects the author criticizes are the dialogue, the temporal dimension of the movie, and the relevance of the events. This, in fact, does not mean that the author does not praise any aspects of the movie. For instance, the author positively comments on the movie's music, cinematography, and the performance of Wadjda and her mother.

Table 2. Number of appraisal expressions in the Arabic review

\begin{tabular}{|c|l|l|l|}
\hline \multirow{4}{*}{$\begin{array}{c}\text { The Arabic Review } \\
\text { (wordcount: 1284) }\end{array}$} & Total positive expressions & 23 & \multirow{3}{*}{ Total 85 } \\
\cline { 2 - 3 } & Total negative expressions & 62 & \\
\cline { 2 - 3 } & Affect & 5 & \multirow{3}{*}{ Total 85 } \\
\cline { 2 - 3 } & Judgement & 44 & 36 \\
\cline { 2 - 3 } & Appreciation & & \\
\hline
\end{tabular}

\section{Text Interpretation}

\section{Text 1}

In the English review, the critic writes for a published magazine which, according to Taboada (2011), indicates that the text is formal, and the critic is keeping a distance between her and the readers. The text consists of seven paragraphs; the first four paragraphs describe the plot of the movie and provide some other events and details to support the critic's claims and evaluation. The evaluation, however, is presented in the last three paragraphs, and it is coupled with some description of the environment and context surrounding the production of the reviewed movie. Any reader of this text can immediately recognize the discourse type of the text and, hence, will find it easy to follow and make their own interpretations without any struggles. An apparent reason for this easiness is the genre the text follows. The critic is following the movie review genre, which essentially consists of two stages: the description and the evaluation. In the description stage, a summary of the movie's plot is often given, and in the evaluation stage, the critic's comments and overall assessment of the movie are presented (Leggett, 2005; Taboada,2011). In this text, both stages can be recognized. Bieler, Dipper, and Stede (2007) stated that opinions of movie critics are rarely combined with the description in one paragraph; however, applying Martin and White's attitude framework to this text shows that the critic's evaluation in this review is not confined to the last three paragraphs. She uses evaluative words and expressions even in the description paragraphs. Considering this movie review genre, the formality and the distance between the critic and the readers explain why attitudinal expressions of judgment and appreciation far outnumber those of affect. Affect adds a more personalized tone to the text while using judgment and appreciation makes the text impersonalized and persuasive (Wu, 2013). In this review, the critic is willing to evaluate the movie and convince the readers of this evaluation.

In the interpretation of this text, many instances of presuppositions and other strategies used for making significance are found. Examples of presuppositions are:

- $\quad$ Eschewing....outspoken radicalism and political passivity

- $\quad$ They are presented as neither vicious fanatics nor cowering victims

- $\quad$ The contradictions of the Saudi society are on display 
In the first example, the critic presupposes that her readers are aware and agree with her about the radicalism and political passivity of Saudi society. By presupposition, she is confirming that this is the case in Saudi Arabia and that there is no doubt about it. In the second example, the critic presupposes that her readers will view girls marrying at a very young age as either fanatics or victims. This presupposition gives more criticism to the society and supports what the critic refers to earlier in the text as restricting rules imposed by the society. In the last example, the critic, again, assumes that the contradictions of Saudi society are not questionable to the readers by using the definite article the in the first mention of contradictions. The critic also attempts to signify these contradictions of the society by using intensifiers and by providing some examples to support her claim. To clarify, appraisal expressions like equally remarkable and inherent are used as intensifying attributes of the word contradictions. To further emphasize the contradictions, the critic presents examples such as the one in the third paragraph about Saudi Arabia being home to Rotana Group, the largest entertainment group in the Arab world. Moreover, the critic demonstrates the lack of movie production in Saudi Arabia as a problem. She tries to emphasize this problem by talking about the number of produced movies in the country, the restrictions imposed on women working with men in public, and the absence of cinemas.

In addition, the critic in her review depicts the social order of the Saudi society in a way that shows this order as problematic. For example:

- $\quad$ "a society that, when they become women, may require them to work outside of the home but will still not allow them to drive."

- "Wadjda uses a bobby pin to attach her name to her father's branch on the tree, but when she enters the room a few days later, the scrap of paper has been taken down. This sad confirmation of the social order happens off screen"

- "Waad Mohammed's family has said they will only allow her to act until she's 16"

- "female actors are generally shunned"

In all these examples that are not entirely drawn from the movie events, the critic attempts to portray the relationships in society. She presents women as always being subjects on which social restrictions and rules are imposed. Another realization of pointing out the relationships in the society is the critic's comment about how the involvement of Prince Alwaleed in the production of the movie gave an official seal to the movie, reflecting another type of the Saudi social hierarchy.

- Prince Alwaleed bin Talal, who owns a majority share in Rotana......, produced Wadjda, Text 2 which gave its more liberal displays an official seal of approval.

The Arabic text is relatively longer than the English one, and it is more evaluative than descriptive in addressing the movie. It has 12 paragraphs, and the first three act as an introduction where the critic talks about the cinema situation in Saudi Arabia in general. Although there are no clear-cut boundaries between the description and evaluation stages, the text is still within the borders of the movie review genera mentioned earlier. Therefore, readers can make sense of the text on this basis. Similar to the English review, this one is published in a popular print newspaper. The critic maintains a degree of formality and distant relationship with the readers, and this can 
justify the higher presentation of judgment and appreciation in the attitudinal expressions as opposed to the affect. The critic yearns to keep his evaluation away from emotions and closer to persuasiveness.

Readers of this text can notice the critic's attempt always to locate his evaluation of the movie within frames of comparisons. For example, there are comparisons with the ideal moviemaker, the previous Saudi movies, Saudi novelists, and Iranian movies and directors. These comparisons might be a deliberate technique the critic uses to alleviate the effect of his negative criticism.

To convince his readers of his arguments, the critic makes several connections. Right from the beginning, the critic made a connection between the responsibility of the director and the quality of the movie by some presuppositions, as in table three.

Table 3. Presuppositions to show the director's responsibility for the movie's quality

\begin{tabular}{|c|c|}
\hline Translation & Or \\
\hline "Wadjda" movi & م المخرجة هيفاء المنصور \\
\hline $\begin{array}{l}\text { When the director's name do } \\
\text { entirely responsible for the mo }\end{array}$ & المخر جندما يتيدو كاملة عن مستوى المخ الفيلم الفيلم.......فإن مسؤولية \\
\hline
\end{tabular}

This connection is laid out from the beginning to justify the writer's abundant criticism of the movie's director. The connection the critic draws continues throughout the review as the director is appraised in about $15 \%$ of the total attitudinal expressions, and all these expressions are negative except one. In contrast, positively evaluated aspects of the movie are mainly attributed to the actors' performance or the German team that contributed to the movie's production. Another connection the critic makes in this text is between women-related issues and Westerners and the cinematic festivals' awards. The critic argues that the movie succeeded in attracting the Westerners because it tackles issues related to women. By drawing such a connection, the critic implies that the movie did not deserve to be nominated for the Oscar.

In another occasion of reproach, the critic depicts the identity of the movie's director, who is also the scriptwriter, as a cinematic activist. By using this metaphor to give the director a different identity, the critic attempts to empower his evaluation and arguments further.

By employing presupposition, the critic tries to convince his readers of the illogical links in the movie. Some examples are in table four.

Table 4. Presuppositions to show the irrational links in the movie

\begin{tabular}{|c|c|}
\hline Translation & Original text \\
\hline $\begin{array}{l}\text { The financial status of the family seems good; however, we } \\
\text { find "Wadjda" struggling to raise money for the bicycle. }\end{array}$ & توفدو قالحالة المادية للأسرة جيدة. ومع هذا نجد وجدة تجاهد لكي \\
\hline How come that 'Wadjda" is given this freedom... & فكيف يتم منح وجدة تلك الحرية المعطاة لها.... \\
\hline $\begin{array}{l}\text { It is irrational that a young child is labored to install lamps } \\
\text { between Wadjda's house and his candidate uncle's house! }\end{array}$ & 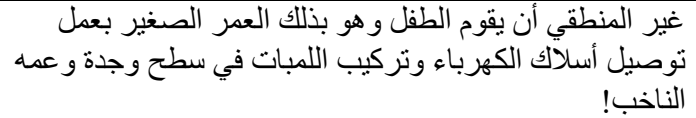 \\
\hline
\end{tabular}

Arab World English Journal for Translation \& Literary Studies 
In these examples, the critic relies on the knowledge he shares with his readers about the society to validate his argument about the irrationality in the movie.

The negative relationship the critic apparently holds toward the movie can be realized in his employment of overwording of negative lexical forms. Words such as irrational, irrationality, crisis, weak, weakness and superficial are recurrent.

\section{Discussion}

In this section, an attempt is to be made to situate the analyzed movie reviews in a broader domain. According to Fairclough (2015), a discourse is a social practice subsumed in a social process that results from social struggle. This means that a discourse affects and is affected by social factors. Therefore, no discourse can be analyzed entirely, without touching upon the social process that leads to the birth of such a discourse.

Interestingly, the texts under analysis in this paper are themselves interpretations of one discourse, Wadjda movie. It is evident from the first stage, in which the attitudinal expressions were extracted, that these reviews interpreted the movie differently. Considering these interpretations socially, it could be claimed that cultural distance is the primary factor. To illustrate, the movie is a Saudi movie that builds, for the most part, on the experiences of the movie's writer in the Saudi society. In the English review, the critic is apparently distant from the Saudi culture. Despite the information she presents in her critique to claim knowledge about the Saudi society, e.g., Prince Alwaleed's perspectives regarding women, she makes her interpretations based on her attitudes and beliefs about this culture.

It casts no doubt that how the Westerns view Arabs or Muslims nowadays is influenced by the media. According to many studies (Abdel Moneim, 2016; Hall, 2001; Macdonald, 2006; Shaheen,2003), the western media have been unfair in their representations of Muslims and Arabs. Arabs are portrayed as primitives, barbarous and terrorists, and women are depicted as oppressed, underprivileged and deprived of their rights and freedom. Considering the circumstances of the movie, being written and directed by a woman and presenting issues related to women's lives in a society known to be conservative, this may have affected the attitude of the English review writer and turned her attention away from giving an in-depth evaluation of aspects concerning the movie itself. On the one hand, most of the critic's evaluative expressions are positive when describing the movie, the director, and the cast. Most negativity, on the other hand, is found directed at the society, and this makes the argument about the influence of the media evident.

Another reason that could be drawn for the critic's positivity towards the movie is the feeling of sympathy with Saudi women's issues, including the obstacles the movie's director had to face to produce the movie. Through her review, the critic attempts to present her support for the movie by shedding light on the social rules and women's struggles in the society. This feeling from the critic could be one of the consequences of the imperial concept of rescuing oppressed women that Spivak (1993) described "White men are saving brown women from brown men" (p.92). The feeling of sympathy and the focus on the social defects could also be a result of Eurocentrism. The Westerns have the sense of superiority over others and claim modernity and 
progress that they want all cultures to have. This may make the acceptance of the differences of other cultures as they are difficult. What is considered part of the norms and traditions to some cultures is viewed as problematic to the Westerns. This reason might have made the critic refrain from addressing the imperfections of the movie negatively and focus more on the negative side of the society. This review sustains the struggle between the West and the Others showing the Westerns as modernity and development seekers who refuse injustice and try to rescue oppressed women.

The second review is written by a Saudi critic, and, therefore, the distance between the critic and the society displayed in the movie does not exist. The critic understands the traditions of the society and, consequently, avoids discussing what is considered to him as cultural or common sense and instead attends more to the evaluation of the cinematic aspects of the movie. The critic here situates his assessment of the movie in a broader area of the Saudi cinematic products. This, in fact, can be realized in many instances where he compares the movie to movies that have been previously produced. In addition, being an insider enables the critic to have a closer and more critical eye for evaluation without being distracted by the social issues presented in the movie. Therefore, issues related to the actors' performance, contradictions of some events, flaws of dialogue, and the temporal dimension of the movie are all discussed in this review but not in the English one.

The concept of the analysis and comparison in this paper is similar to the one conducted by Griswold (1987). She investigated how reviewers from different cultures evaluate the works of the novelist George Lamming, a mid- $20^{\text {th }}$ century author. She found that the novels of Lamming had different interpretations among the critics, concluding that cultural products derive their meanings from the recipients' social context. Considering movies as cultural products, the variation in the critics' evaluation of Wadjda could be justified on the grounds of the social and cultural context as well.

\section{Conclusion}

This paper sought to examine two reviews of the movie Wadjda, one written by a western critic and the other is written by a Saudi critic. The aim is to find how different the evaluation of the movie is by the two critics. By analyzing the two texts for their attitudinal expressions, it was found that the English text maintains an even distribution between the negative and positive expressions and most of the negative expressions did not assess the aspects of the movie but rather the Saudi society. In the Arabic text, however, the negative expressions outnumbered the positive ones, and they were mostly related to the movie and the director. It is believed that the western critic avoided negative criticism of the movie itself for several reasons. It might be the influence of Eurocentrism and the western media and the way they represent the Arabs and Muslims. The result could be the feeling of sympathy with women's issues and, hence, the feeling of being pledged to support women who, as the media present them, are suffering in their societies. The Arabic review, however, provided a more critical assessment of different aspects of the movie. This can be explained based on the critic being part of the society and, thus, not distracted by the social issues which allow him to have a deeper insight and provide a more objective evaluation of the movie.

Arab World English Journal for Translation \& Literary Studies 


\section{About the author:}

Maram S. Almohaimeed is working at King Saud University (KSU). She holds M.A. degree in Applied Linguistics from the College of Languages and Translation at KSU. Her research interests revolve around discourse analysis and foreign language teaching and learning. ORCID ID: https://orcid.org/0000-0002-0275-3239

\section{References}

Abdel Moneim, Y. (2016). Sourat Almar'ah Alarabiah fi Alsahafa Alamrekiah wa Al Britaniah [Representation of Arab women in the American and British Journalism]. Al Arabi Publishing and Distributing.

Assael, H. (1984). Consumer behavior and marketing action. Kent Pub. Co.

Bieler, H., Dipper, S., \& Stede, M. (2007). Identifying formal and functional zones in film reviews. Proceedings of the 8th SIGDIAL, 75-78.

Fairclough, N. (2015). Language and Power: London. Routledge.

Gee, J. P. (2014). An introduction to discourse analysis: Theory and method. Routledge.

Griswold, W. (1987). The fabrication of meaning: Literary interpretation in the United States, Great Britain, and the West Indies. American Journal of Sociology, 92(5), 1077-1117. https://doi.org/10.1086/228628

Hall, A. (2001). Film reviews and the public's perceptions of stereotypes: Movie critics' discourse about The Siege. Communication Quarterly, 49(4), 399-423. https://doi.org/10.1080/01463370109385638

Hobson, J., 2006. East and West in global history. Theory, Culture and Society, 23 (2-3), 408410. https://doi.org/10.1177/026327640602300273

Hsu, G. (2006). Evaluative schemas and the attention of critics in the US film industry. Industrial and Corporate Change, 15(3), 467-496.

Kassimeris, G., \& Jackson, L. (2011). The West, the rest, and the 'war on terror': Representation of Muslims in neoconservative media discourse. Contemporary politics, 17(1), 19-33. https://doi.org/10.1080/13569775.2011.552684

Leggett, B. J. (2005). Convergence and divergence in the movie review: Bonnie and Clyde. Film Criticism, 30(2). 1-23.

Litman, B. R. (1983). Predicting success of theatrical movies: An empirical study. Journal of popular culture, 16(4), 159.

Macdonald, M. (2006). Muslim women and the veil: Problems of image and voice in media representations. Feminist Media Studies, 6(1), 7-23.

Martin J. R., \& White P. R. R. (2005). The Language of Evaluation: Appraisal in English. Palgrave, London. Retrieved from (http://grammatics.com/appraisal/)

Riasati, M. J., \& Rahimi, F. (2011). Critical discourse analysis: Scrutinizing ideologically-driven discourses. International journal of humanities and social science, 1, 16.

Ridouani, D. (2011). The representation of Arabs and Muslims in western media. Ruta: revista universitària de treballs acadèmics, 2(3), 45-57.

Shaheen, J. G. (2003). Reel bad Arabs: How Hollywood vilifies a people. The Annals of the American Academy of Political and Social Science, 588(1), 171-193. https://doi.org/10.1177/0002716203588001011

Arab World English Journal for Translation \& Literary Studies 
Spivak, G. (1993). Can the subaltern speak? In Williams, P., \& Chrisman, L. (Eds.), Colonial discourse and post-colonial theory: A reader (pp. 66-111). Columbia University Press.

Taboada, M. (2011). Stages in an online review genre. Text \& Talk-An Interdisciplinary Journal of Language, Discourse \& Communication Studies, 31(2), 247-269.

Teo, P. (2000). Racism in the news: A critical discourse analysis of news reporting in two Australian newspapers. Discourse \& Society, 11(1), 7-49.

Thompson, G. (2014). Introducing functional grammar. Routledge.

Van Dijk, T. A. (1995). Discourse semantics and ideology. Discourse \& society, 6(2), 243-289.

Verschueren, J. (2015). Ideology in discourse. The International Encyclopedia of Language and Social Interaction (2), 768-778. Malden, MA: Wiley Blackwell.

Weimann, G. (1991). The influentials: back to the concept of opinion leaders?. Public Opinion Quarterly, 55(2), 267-279.https://doi.org/10.1086/269257

$\mathrm{Wu}, \mathrm{H}$. B. (2013). Appraisal perspective on attitudinal analysis of public service advertising discourse. English Language and Literature Studies, 3(1), 55.

Appendices

Appendix A

Movie Reviews

\section{Review (1)}

By Violet Lucca on August 26, 2013

Retrieved from https://www.filmcomment.com/blog/review-wadjda-haifa-al-mansour/

Review (2)

By Tami Alsumairi on October 5, 2013

Retrieved from http://www.alriyadh.com/873027

\begin{tabular}{|c|c|c|c|c|c|c|c|}
\hline \multicolumn{8}{|c|}{$\begin{array}{c}\text { Appendix B } \\
\text { Analysis of the English review }\end{array}$} \\
\hline No & Appraising Items & Appraiser & A & $\mathrm{J}$ & $\mathrm{P}$ & Appraised & $\mathrm{O}$ \\
\hline & \multicolumn{7}{|c|}{$\mathrm{A}=$ Affect, $\mathrm{J}=$ Judgement, $\mathrm{P}=$ Appreciation, $\mathrm{O}=$ Orientation, $\mathrm{P}=$ Positive, $\mathrm{N}=$ Negative } \\
\hline 1 & Eschewing & Writer & & * & & Director & $\mathrm{N}$ \\
\hline 2 & Outspoken radicalism & Writer & & $*$ & & Saudi society & $\mathrm{N}$ \\
\hline 3 & Political passivity & Writer & & $*$ & & Saudi society & $\mathrm{N}$ \\
\hline 4 & Firm & Writer & & $*$ & & Movie & $\mathrm{P}$ \\
\hline 5 & Understated & Writer & & $*$ & & Movie & $\mathrm{N}$ \\
\hline 6 & Endearing & Writer & & & $*$ & Movie story & $\mathrm{P}$ \\
\hline 7 & Coming-of-age & Writer & & & $*$ & Movie story & $\mathrm{P}$ \\
\hline 8 & Adorable & Writer & & & $*$ & Wadjda/movie & $\mathrm{P}$ \\
\hline 9 & Natural & Writer & & $*$ & & Wadjda/movie & $\mathrm{P}$ \\
\hline 10 & Full of nerve & Writer & & & $*$ & Wadjda/movie & $\mathrm{P}$ \\
\hline 11 & Comfortable existence & Writer & & & $*$ & Environment/movie & $\mathrm{P}$ \\
\hline 12 & Middle-class & Writer & & $*$ & & Family/movie & $\mathrm{P}$ \\
\hline 13 & Urban & writer & & $*$ & & Family/movie & $\mathrm{P}$ \\
\hline 14 & Pushes back..against & writer & & $*$ & & Wadjda/movie & $\mathrm{P}$ \\
\hline 15 & Hem her in & writer & & $*$ & & Social rules/movie & $\mathrm{N}$ \\
\hline 16 & Beautiful & writer & & & $*$ & Bike/movie & $\mathrm{P}$ \\
\hline 17 & New & writer & & $*$ & & Bike/movie & $\mathrm{P}$ \\
\hline 18 & Put Pee Wee's to shame & writer & & & $*$ & Wadjda & $\mathrm{P}$ \\
\hline
\end{tabular}

Arab World English Journal for Translation \& Literary Studies 
AWEJ for Translation \& Literary Studies Volume, 5 Number 3. August 2021

\begin{tabular}{|c|c|c|c|c|c|c|c|}
\hline 19 & Difficult & Wadjda & * & & & Raising money/movie & $\mathrm{N}$ \\
\hline 20 & Eagerly & Wadjda & $*$ & & & $\begin{array}{l}\text { Joining the Koran } \\
\text { competition/movie }\end{array}$ & $\mathrm{P}$ \\
\hline 21 & In hopes of & Wadjda & $*$ & & & Winning the prize/movie & $\mathrm{P}$ \\
\hline 22 & Humorous & writer & & $*$ & & $\begin{array}{l}\text { Wadjda's effort to master } \\
\text { Qur'anic text/movie }\end{array}$ & $\mathrm{P}$ \\
\hline 23 & Mundane universality & writer & & & $*$ & Wadjda's efforts & $\mathrm{P}$ \\
\hline 24 & Keeps getting stuck & writer & & $*$ & & Wadjda & $\mathrm{N}$ \\
\hline 25 & Arcane question & writer & & & * & $\begin{array}{l}\text { Question about Qur'anic } \\
\text { meaning }\end{array}$ & $\mathrm{N}$ \\
\hline 26 & Deeply moving & writer & * & & & Wadjda's efforts & $\mathrm{P}$ \\
\hline 27 & Not especially devout & writer & & * & & Wadjda/movie & $\mathrm{N}$ \\
\hline 28 & Different & writer & & $*$ & & Girls/movie & $\mathrm{N}$ \\
\hline 29 & More conservative & writer & & $*$ & & $\begin{array}{l}\text { The family of the club } \\
\text { student/movie }\end{array}$ & $\mathrm{N}$ \\
\hline 30 & Neither vicious fanatics & writer & & $*$ & & $\begin{array}{l}\text { The girls in the religious } \\
\text { club/movie }\end{array}$ & $\mathrm{N}$ \\
\hline 31 & Nor cowering victims & writer & & $*$ & & $\begin{array}{l}\text { The girls in the religious } \\
\text { club/movie }\end{array}$ & $\mathrm{P}$ \\
\hline 32 & Simply girls & writer & & $*$ & & The school girls & $\mathrm{P}$ \\
\hline 33 & Require them to work outside & writer & & $*$ & & Saudi society & $\mathrm{N}$ \\
\hline 34 & Still not allow them to drive & writer & & * & & Saudi society & $\mathrm{N}$ \\
\hline 35 & Traditionally minded & writer & & $*$ & & Wadjda's mother/movie & $\mathrm{N}$ \\
\hline 36 & Somber & writer & & * & & Sequence of scenes & $\mathrm{N}$ \\
\hline 37 & Sad confirmation & writer & $*$ & & & Social order/society & $\mathrm{N}$ \\
\hline 38 & Strict & writer & & $*$ & & Headmistress/movie & $\mathrm{N}$ \\
\hline 39 & Contradictions & writer & & & $*$ & Saudi society & $\mathrm{N}$ \\
\hline 40 & Never belabored & writer & & $*$ & & The contradictions/society & $\mathrm{N}$ \\
\hline 41 & Far poorer & writer & & $*$ & & $\begin{array}{l}\text { Living condition of the } \\
\text { driver/movie }\end{array}$ & $\mathrm{N}$ \\
\hline 42 & Remarkable...the contradictions & Writer & & & * & $\begin{array}{l}\text { The Saudi context where } \\
\text { the movie is made }\end{array}$ & $\overline{\mathrm{N}}$ \\
\hline 43 & Home to Rotana & Writer & & & $*$ & Saudi Arabia & $\mathrm{P}$ \\
\hline 44 & The Arab world's largest & Writer & & & * & $\begin{array}{l}\text { Rotana, entertainment } \\
\text { company }\end{array}$ & $\mathrm{P}$ \\
\hline 45 & Produced less than. & Writer & & $*$ & & Saudi Arabia & $\mathrm{N}$ \\
\hline 46 & No Saudi-made films & Writer & & $*$ & & Saudi Arabia & $\mathrm{N}$ \\
\hline 47 & complained & $\begin{array}{l}\text { prince } \\
\text { Alwaleed }\end{array}$ & $*$ & & & Forbes & $\mathrm{N}$ \\
\hline 48 & undervaluing & Forbes & & & $*$ & Prince Alwaleed & $\mathrm{N}$ \\
\hline 49 & Gave....an official seal & Writer & & & $*$ & Prince Alwaleed & $\mathrm{P}$ \\
\hline 50 & More liberal & Writer & & $*$ & & Displays of the movie & $\begin{array}{l}\mathrm{p} \\
\mathrm{P}\end{array}$ \\
\hline 51 & Supports women driving & Writer & & & $*$ & Prince Alwaleed & $\mathrm{P}$ \\
\hline 52 & Employs many women & Writer & & & $*$ & Prince Alwaleed & $\mathrm{P}$ \\
\hline 53 & Didn't make the ... any easier & Writer & & & $*$ & Prince Alwaleed & $\mathrm{N}$ \\
\hline 54 & The government ban & Writer & & $*$ & & Saudi society & $\mathrm{N}$ \\
\hline 55 & Had to communicate & Writer & & & $*$ & Saudi society & $\mathrm{N}$ \\
\hline 56 & Significant talents & Writer & & & $*$ & The heroine & $\mathrm{P}$ \\
\hline 57 & Only allow her...until she's 16 & Writer & & $*$ & & Heroine's family & $\mathrm{N}$ \\
\hline 58 & Generally shunned & Writer & & $*$ & & $\begin{array}{l}\text { Female actors in Saudi } \\
\text { Arabia }\end{array}$ & $\mathrm{N}$ \\
\hline
\end{tabular}

Arab World English Journal for Translation \& Literary Studies

ISSN: 2550-1542 | www.awej-tls.org 
AWEJ for Translation \& Literary Studies Volume, 5 Number 3. August 2021 Evaluation of Wadjda: A Comparative Discourse Analysis of Western

Almohaimeed

\begin{tabular}{|l|l|l|l|l|l|l|l|}
\hline 59 & Genuinely tender & Writer & & & $*$ & The movie's denouement & P \\
\hline 60 & Gives a sense of freedom and hope & Writer & & & $*$ & The movie's closing image & P \\
\hline 61 & Offers solace & Writer & & & $*$ & The movie's closing image & P \\
\hline 62 & Conservative & Writer & & $*$ & & Movie viewers & N \\
\hline 63 & Liberal & Writer & & $*$ & & Movie viewers & P \\
\hline 64 & Won't be able to see & Writer & & $*$ & & average Saudis & N \\
\hline 65 & Were banned & Writer & & $*$ & & $\begin{array}{l}\text { Theaters and movie parlors } \\
\text { in SA }\end{array}$ & N \\
\hline 66 & Considerable & Writer & & & $*$ & $\begin{array}{l}\text { The director's } \\
\text { accomplishment }\end{array}$ & P \\
\hline
\end{tabular}

\section{Appendix C}

Analysis of the Arabic Review

\begin{tabular}{|c|c|c|c|c|c|c|c|c|}
\hline & \multicolumn{8}{|c|}{$\mathrm{A}=$ Affect, $\mathrm{J}=$ Judgement $\mathrm{P}=$ Appreciation, $\mathrm{O}=$ Orientation, $\mathrm{P}=$ Positive, $\mathrm{N}=$ Negative } \\
\hline No. & appraising & & appraiser & A & $\mathbf{J}$ & $\mathrm{P}$ & appraised & $\mathrm{O}$ \\
\hline & original text & translation & & & & & & \\
\hline 1 & المفارقة الغريية & weird contradictory & writer & & & * & $\begin{array}{l}\text { production } \\
\text { of Saudi } \\
\text { films }\end{array}$ & $\mathrm{N}$ \\
\hline 2 & كل عناصر الحالة السينمائية موجودة & $\begin{array}{l}\text { all cinematic elements } \\
\text { are present }\end{array}$ & writer & & * & & $\begin{array}{l}\text { production } \\
\text { of Saudi } \\
\text { films }\end{array}$ & $\mathrm{P}$ \\
\hline 3 & يظل بعيدا عن الجمهور & $\begin{array}{l}\text { still far from the } \\
\text { audience }\end{array}$ & writer & & * & & $\begin{array}{l}\text { cinematic } \\
\text { work }\end{array}$ & $\mathrm{N}$ \\
\hline 4 & عدم وجود صالات لعرض السينما & $\begin{array}{l}\text { the absence of cinema } \\
\text { halls }\end{array}$ & writer & & * & & $\begin{array}{l}\text { Saudi } \\
\text { society }\end{array}$ & $\mathrm{N}$ \\
\hline 5 & 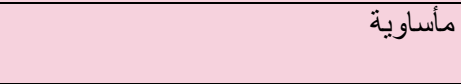 & miserable & writer & * & & & $\begin{array}{l}\text { situation of } \\
\text { cinema }\end{array}$ & $\mathrm{N}$ \\
\hline 6 & غياب اللفتة الإبداعية & absence of creativity & writer & & & * & $\begin{array}{l}\text { cinema } \\
\text { production }\end{array}$ & $\mathrm{N}$ \\
\hline 7 & عدم وجود الفيلم السينمائي & $\begin{array}{l}\text { absence of cinema } \\
\text { movies }\end{array}$ & writer & & * & & $\begin{array}{l}\text { cinema } \\
\text { situation }\end{array}$ & $\mathrm{N}$ \\
\hline 8 & يسنطيع أن يتجاوز & can overcome & writer & & * & & $\begin{array}{l}\text { real film- } \\
\text { maker }\end{array}$ & $\mathrm{P}$ \\
\hline 9 & يمتع المشـاهد & to entertain the viewers & writer & & & * & $\begin{array}{l}\text { real film- } \\
\text { maker }\end{array}$ & $P$ \\
\hline 10 & قادر على استثمار & able to invest & writer & & * & & $\begin{array}{l}\text { real film- } \\
\text { maker }\end{array}$ & $\mathrm{P}$ \\
\hline 11 & فرصة الإنتاج الجيدة & $\begin{array}{l}\text { good production } \\
\text { opportunity }\end{array}$ & writer & & * & & $\begin{array}{l}\text { production } \\
\text { in Wadjda } \\
\text { movie }\end{array}$ & $\mathrm{P}$ \\
\hline 12 & فيلم "وجدة" مرتبطا باسم المخرجة & $\begin{array}{l}\text { Wadjda movie is } \\
\text { associated with the } \\
\text { director's name }\end{array}$ & writer & & & * & the movie & $\mathrm{N}$ \\
\hline 13 & يهيمن اسم المخرج & $\begin{array}{l}\text { the director's name is } \\
\text { dominating }\end{array}$ & writer & & * & & the movie & $\mathrm{N}$ \\
\hline 14 & تتوارى أسماء الممثلين & $\begin{array}{l}\text { names of the are } \\
\text { backgrounded }\end{array}$ & writer & & * & & the movie & $\mathrm{N}$ \\
\hline 15 & يمنحنا الأمل & gives us hope & writer & $*$ & & & the movie & $\mathrm{P}$ \\
\hline 16 & ليست مستحيلة & not impossible & writer & & & $*$ & $\begin{array}{l}\text { production } \\
\text { of feature } \\
\text { films }\end{array}$ & $\mathrm{P}$ \\
\hline
\end{tabular}

Arab World English Journal for Translation \& Literary Studies

ISSN: 2550-1542 | www.awej-tls.org 
AWEJ for Translation \& Literary Studies Volume, 5 Number 3. August 2021 Evaluation of Wadjda: A Comparative Discourse Analysis of Western

\begin{tabular}{|c|c|c|c|c|c|c|c|c|}
\hline 17 & الأمل السينمائي & the cinema hope & writer & $*$ & & & the movie & $\mathrm{P}$ \\
\hline 18 & التصوير الجيد & good cinematography & writer & & $*$ & & the movie & $\mathrm{P}$ \\
\hline 19 & الموسيقى التصويرية الجيدة & good music & writer & & $*$ & & the movie & $\mathrm{P}$ \\
\hline 20 & لعب دورا & played a role & writer & & & $*$ & $\begin{array}{l}\text { the German } \\
\text { production } \\
\text { team }\end{array}$ & $\mathrm{P}$ \\
\hline 21 & هذا التميز & this excellence & writer & & & $*$ & the movie & $\mathrm{P}$ \\
\hline 22 & مثقلة بالحالة السلبية & $\begin{array}{l}\text { burdened with } \\
\text { negativity }\end{array}$ & writer & & & $*$ & the director & $\mathrm{N}$ \\
\hline 23 & فرط حماسها & $\begin{array}{l}\text { her excessive } \\
\text { excitement }\end{array}$ & writer & & $*$ & & the director & $\mathrm{N}$ \\
\hline 24 & تعلقها بالهم النسائي & $\begin{array}{l}\text { her concern about } \\
\text { women issues }\end{array}$ & writer & & $*$ & & the director & $\mathrm{N}$ \\
\hline 25 & ناشطة سينمائية & cinematic activist & writer & & $*$ & & the director & $\mathrm{N}$ \\
\hline 26 & بالحماس العاطفي & emotional excitement & writer & & & $*$ & the director & $\mathrm{N}$ \\
\hline 27 & دون تبصر & without an insight & writer & & & $*$ & the director & $\mathrm{N}$ \\
\hline 28 & دون...عمت فني & without.. Artistic depth & writer & & & $*$ & the director & $\mathrm{N}$ \\
\hline 29 & مجرد عمل سبنمائي طارئ & a mere emergent work & writer & & & $*$ & the movie & $\mathrm{N}$ \\
\hline 30 & جاذبيته تكمن فقط & $\begin{array}{l}\text { its attraction is found } \\
\text { only in.. }\end{array}$ & writer & & & $*$ & the movie & $\mathrm{N}$ \\
\hline 31 & بشكل سطحي & superficially & writer & & $*$ & & the movie & $\mathrm{N}$ \\
\hline 32 & دون الذهاب إلى العمق الإنساني & $\begin{array}{l}\text { without addressing the } \\
\text { humanitarian depth }\end{array}$ & writer & & $*$ & & the movie & $\mathrm{N}$ \\
\hline 33 & موضوع جاذب & an attractive topic & writer & & & $*$ & $\begin{array}{l}\text { Women's } \\
\text { issues }\end{array}$ & $\mathrm{N}$ \\
\hline 34 & يباركون & congratulate & writer & & $*$ & & $\begin{array}{l}\text { the } \\
\text { Westerns }\end{array}$ & $\mathrm{N}$ \\
\hline 35 & ميزة التعاطف مع قضايانا & $\begin{array}{l}\text { the sense of sympathy } \\
\text { with our issues }\end{array}$ & writer & $*$ & & & $\begin{array}{l}\text { the } \\
\text { Westerns }\end{array}$ & $\mathrm{N}$ \\
\hline 36 & يعطل الإبداع & hinders creativity & writer & & & $*$ & $\begin{array}{l}\text { addressing } \\
\text { women's } \\
\text { issues }\end{array}$ & $\mathrm{N}$ \\
\hline 37 & لايها ذات الأزمة & has the same crisis & writer & & $*$ & & the director & $\mathrm{N}$ \\
\hline 38 & يعاني منها & suffer from & writer & & $*$ & & $\begin{array}{l}\text { Saudi } \\
\text { novelists }\end{array}$ & $\mathrm{N}$ \\
\hline 39 & يحشد كل مشاكل المجتمع & $\begin{array}{l}\text { compile all the society's } \\
\text { issues }\end{array}$ & writer & & & $*$ & $\begin{array}{l}\text { Saudi } \\
\text { novelists \& } \\
\text { the director }\end{array}$ & $\mathrm{N}$ \\
\hline 40 & دون التفكر & without thinking & writer & & $*$ & & $\begin{array}{l}\text { Saudi } \\
\text { novelists \& } \\
\text { the director }\end{array}$ & $\mathrm{N}$ \\
\hline 41 & محتشد بالمشاهد الزائدة التي لاتخدم العمل & $\begin{array}{l}\text { packed with } \\
\text { unnecessary scenes that } \\
\text { don't serve the work }\end{array}$ & writer & & $*$ & & the movie & $\mathrm{N}$ \\
\hline 42 & فقط تشير إلى أن هذا العمل .. & only to indicate... & writer & & $*$ & & the movie & $\mathrm{N}$ \\
\hline 43 & حاولت ...الاقتر اب & tried..to get closer & writer & & $*$ & & the director & $\mathrm{N}$ \\
\hline 44 & نجح & succeeded & writer & & & $*$ & $\begin{array}{l}\text { Iranian } \\
\text { directors }\end{array}$ & $\mathrm{P}$ \\
\hline 45 & أصبحت تللك الثيمة عبئًاً & $\begin{array}{l}\text { this theme has become } \\
\text { a burden }\end{array}$ & writer & & & $*$ & $\begin{array}{l}\text { the theme in } \\
\text { Iranian } \\
\text { movies and } \\
\text { "Wadjda" }\end{array}$ & $\mathrm{N}$ \\
\hline
\end{tabular}

Arab World English Journal for Translation \& Literary Studies

ISSN: 2550-1542 | www.awej-tls.org 
AWEJ for Translation \& Literary Studies Volume, 5 Number 3. August 2021 Evaluation of Wadjda: A Comparative Discourse Analysis of Western

Almohaimeed

\begin{tabular}{|c|c|c|c|c|c|c|c|c|}
\hline 46 & هي ذات النموذج الطفولي & $\begin{array}{l}\text { is identical to the } \\
\text { childhood model }\end{array}$ & writer & & & * & the movie & $\mathrm{N}$ \\
\hline 47 & ماجعل الفيلم له قبول & $\begin{array}{l}\text { what makes the movie } \\
\text { welcomed }\end{array}$ & writer & & & $*$ & the movie & $\mathrm{P}$ \\
\hline 48 & استطاعت أن تقدم & could present & writer & & $*$ & & $\begin{array}{l}\text { the movie } \\
\text { star } \\
\text { "Wadjda" }\end{array}$ & $P$ \\
\hline 49 & 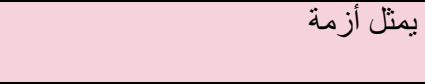 & is problematic & writer & & $*$ & & $\begin{array}{l}\text { the movie's } \\
\text { dialogue }\end{array}$ & $\mathrm{N}$ \\
\hline 50 & نقطة الضعف الأزلية & ancient weakness & writer & & $*$ & & Saudi drama & $\mathrm{N}$ \\
\hline 51 & هذا الضعف تجلى & this weakness appears & writer & & * & & $\begin{array}{l}\text { the movie's } \\
\text { dialogue }\end{array}$ & $\mathrm{N}$ \\
\hline 52 & غير منطقي & irrational & writer & & & $*$ & $\begin{array}{l}\text { the movie's } \\
\text { dialogue }\end{array}$ & $\mathrm{N}$ \\
\hline 53 & يغلب عليها طابع الخطابية & $\begin{array}{l}\text { mostly sounded like } \\
\text { reading from the script }\end{array}$ & writer & & & * & $\begin{array}{l}\text { the movie's } \\
\text { dialogue }\end{array}$ & $\mathrm{N}$ \\
\hline 54 & هش & fragile & writer & & $*$ & & $\begin{array}{l}\text { the movie's } \\
\text { dialogue }\end{array}$ & $\mathrm{N}$ \\
\hline 55 & قليلة & a few & writer & & $*$ & & $\begin{array}{l}\text { scenes with } \\
\text { good } \\
\text { dialogue }\end{array}$ & $\mathrm{N}$ \\
\hline 56 & الضعف الظاهر & clear weakness & writer & & & * & $\begin{array}{l}\text { the movie's } \\
\text { dialogue }\end{array}$ & $\mathrm{N}$ \\
\hline 57 & كان الحوار ضعيفاً & the dialogue was weak & writer & & * & & $\begin{array}{l}\text { the movie's } \\
\text { dialogue }\end{array}$ & $\mathrm{N}$ \\
\hline 58 & فكيف ينتم منح وجدة تلك الحرية & $\begin{array}{l}\text { how come that Wadjda } \\
\text { was given such freedom }\end{array}$ & writer & & $*$ & & $\begin{array}{l}\text { the movie } \\
\text { (rationale) }\end{array}$ & $\mathrm{N}$ \\
\hline 59 & حالة من اللامنطقية & irrationality & writer & & & $*$ & $\begin{array}{l}\text { the role of } \\
\text { Wadjda/the } \\
\text { movie }\end{array}$ & $\mathrm{N}$ \\
\hline 60 & البعد عن الصدق الفني & $\begin{array}{l}\text { being far from artistic } \\
\text { honesty }\end{array}$ & writer & & & * & $\begin{array}{l}\text { the role of } \\
\text { Wadjda/the } \\
\text { movie }\end{array}$ & $\mathrm{N}$ \\
\hline 61 & مربكاً & confusing & writer & & & * & $\begin{array}{l}\text { the movie's } \\
\text { time }\end{array}$ & $\mathrm{N}$ \\
\hline 62 & 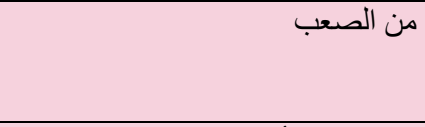 & it was difficult & writer & & & * & $\begin{array}{l}\text { the movie's } \\
\text { temporal } \\
\text { dimension }\end{array}$ & $\mathrm{N}$ \\
\hline 63 & مع هذا نجد أن شانشة البلازما حاضرة & $\begin{array}{l}\text { yet the plasma TV was } \\
\text { there }\end{array}$ & writer & & * & & $\begin{array}{l}\text { the movie's } \\
\text { temporal } \\
\text { dimension }\end{array}$ & $\mathrm{N}$ \\
\hline 64 & كان مقحماً & was barged into & writer & & & $*$ & $\begin{array}{l}\text { the elections } \\
\text { scene }\end{array}$ & $\mathrm{N}$ \\
\hline 65 & غير المنطقي & irrational & writer & & & * & $\begin{array}{l}\text { the role of } \\
\text { Wadjda's } \\
\text { friend }\end{array}$ & $\mathrm{N}$ \\
\hline 66 & تفاجئنا & surprised us & writer & $*$ & & & $\begin{array}{l}\text { the mother's } \\
\text { action }\end{array}$ & $\mathrm{N}$ \\
\hline 67 & بغير مبرر & $\begin{array}{l}\text { without any } \\
\text { justification }\end{array}$ & writer & & & * & $\begin{array}{l}\text { the mother's } \\
\text { action }\end{array}$ & $\mathrm{N}$ \\
\hline 68 & لا يتناسب & not suitable for & writer & & $*$ & & $\begin{array}{l}\text { the mother's } \\
\text { action }\end{array}$ & $\mathrm{N}$ \\
\hline
\end{tabular}

Arab World English Journal for Translation \& Literary Studies

ISSN: 2550-1542 | www.awej-tls.org 
AWEJ for Translation \& Literary Studies Volume, 5 Number 3. August 2021 Evaluation of Wadjda: A Comparative Discourse Analysis of Western

\begin{tabular}{|c|c|c|c|c|c|c|c|}
\hline 69 & لم تستطع المخرجة إقناعنا & couldn't convince us & writer & $*$ & & the director & $\mathrm{N}$ \\
\hline 70 & لم يكن ماييرره & was not justified & writer & & $*$ & $\begin{array}{l}\text { the role of } \\
\text { the mother's } \\
\text { friend }\end{array}$ & $\mathrm{N}$ \\
\hline 71 & افتتعال أزمة زواج و الد وجدة & $\begin{array}{l}\text { fabricating the problem } \\
\text { of Wadjda's father } \\
\text { marriage }\end{array}$ & writer & * & & $\begin{array}{l}\text { the movie } \\
\text { events }\end{array}$ & $\mathrm{N}$ \\
\hline 72 & لفتتة قد تحسب للمخرجة & a strength point & writer & $*$ & & the director & $\mathrm{P}$ \\
\hline 73 & بر اعة مو هبة & brilliant skill & writer & & $*$ & $\begin{array}{l}\text { the movie } \\
\text { star } \\
\text { "Wadjda" }\end{array}$ & $\mathrm{P}$ \\
\hline 74 & كان ضعيفاً & was weak & writer & $*$ & & $\begin{array}{l}\text { the cast } \\
\text { performance }\end{array}$ & $\mathrm{N}$ \\
\hline 75 & بخبرتها وتمرسها & her experience & writer & & $*$ & the mother & $\mathrm{P}$ \\
\hline 76 & أكثر تلقائية & more natural & writer & $*$ & & the mother & $\mathrm{P}$ \\
\hline 77 & أكثر.. قدرة على الأداء & $\begin{array}{l}\text { more skillful } \\
\text { performance }\end{array}$ & writer & * & & the mother & $\mathrm{P}$ \\
\hline 78 & كان مقنعاً & was convincing & writer & & * & $\begin{array}{l}\text { the } \\
\text { performance } \\
\text { of the man } \\
\text { working in } \\
\text { the bicycles' } \\
\text { store }\end{array}$ & $\mathrm{P}$ \\
\hline 79 & كان ضعيفا في المشاهد الأولى & $\begin{array}{l}\text { was weak in the first } \\
\text { scenes }\end{array}$ & writer & $*$ & & $\begin{array}{l}\text { the } \\
\text { performance } \\
\text { of the } \\
\text { school } \\
\text { principal }\end{array}$ & $\mathrm{N}$ \\
\hline 80 & كانت أكثر إقناعا & was more convincing & writer & & * & $\begin{array}{l}\text { the } \\
\text { performance } \\
\text { of the } \\
\text { school } \\
\text { principal }\end{array}$ & $\mathrm{P}$ \\
\hline 81 & الثغرات الفنية & artistic flaws & writer & * & & the movie & $\mathrm{N}$ \\
\hline 82 & إلا أنه فيلم جاذب للمشاهدة & $\begin{array}{l}\text { yet it is an attractive } \\
\text { movie to watch }\end{array}$ & writer & & * & the movie & $\mathrm{P}$ \\
\hline 83 & و لا تكتفي بنقل ما هو على سطح المجتمع & $\begin{array}{l}\text { not only transfer the } \\
\text { society's superficial } \\
\text { issues }\end{array}$ & writer & * & & the director & $\mathrm{N}$ \\
\hline 84 & أن لا تستجيب لإغر اء الموضو عات & $\begin{array}{l}\text { not to be tempted by } \\
\text { some topics }\end{array}$ & writer & * & & the director & $\mathrm{N}$ \\
\hline 85 & تتخلى عن عباءة الناشطة السينمائية & $\begin{array}{l}\text { to abandon the veil of } \\
\text { the cinematic activist }\end{array}$ & writer & $*$ & & the director & $\mathrm{N}$ \\
\hline
\end{tabular}

Arab World English Journal for Translation \& Literary Studies 